引用格式: 石育中, 李文龙, 鲁大铭, 等. 基于乡镇尺度的黄土高原干旱脆弱性时空演变分析一一以榆中县为例[J]. 资源科学, 2017, 39 (11) : 2130-2140. [Shi Y Z, Li W L, Lu D M, et al. Spatio-temporal analysis of drought vulnerability on the Loess Plateau of China at town level[J]. Resources Science, 2017,39(11):2130-2140.] DOI: 10.18402/resci.2017.11.11

\title{
基于乡镇尺度的黄土高原干旱脆弱性时空演变分析 以榆中县为例
}

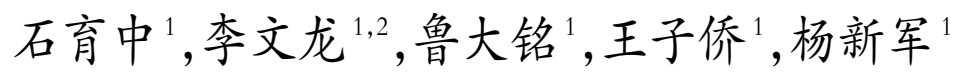

(1. 西北大学城市与环境学院, 西安 710127; 2. 内蒙古财经大学资源与环境经济学院, 呼和浩特 010070)

摘 要: 干旱脆弱性评价是干旱半干旱地区人地关系研究的重要内容, 对减缓和应对干旱具有重要作用, 乡镇 尺度的干旱脆弱性评价为西北乡村人地系统可持续性研究提供新的视角。本文引用干旱脆弱性分析框架, 从暴露 度、敏感性和适应能力三个维度构建指标体系,选择甘肃榆中县作为黄土高原典型研究区域,采用2002-2015 年统 计数据、气象数据和遥感数据, 运用摘值法、综合指数法和局部空间自相关指数法等分析方法分别对指标权重、干 旱脆弱性指数与类型及其空间集聚性进行分析。研究结果表明: (1)榆中县干旱脆弱性指数呈波动式变化趋势, 阶 段性升降明显; (2)不同脆弱类型的乡镇数量由高到低分别为中脆弱 > 高脆弱 > 低脆弱, 且高脆弱的乡镇数量增加趋 势明显; (3)干旱脆弱性影响因素由高到低分别为年降水量、坡度、年平均气温、千旱影响面积、农民纯收入、人口密 度和农业人口比例, 年降水量为干旱脆弱性的首要决定因素; (4)干旱脆弱性热点区域总体格局呈现“南-北热中部 冷”的空间格局, 具有明显的地理集聚特征, 且局部乡镇热点区域趋于稳定。

关键词: 千旱脆弱性指数; Getis-Ord G*; 时空演变; 影响因素; 黄土高原

DOI: $10.18402 /$ resci.2017.11.11

\section{1 引言}

随着全球变暖与干旱趋势的加剧,已严重威胁 到人类的粮食安全、水资源利用和生态环境稳定, 对人地耦合系统可持续性产生巨大影响 ${ }^{[1-5]}$ 。干旱 脆弱性是人地系统受干旱胁迫而影响系统应对能 力的状态, 是由自然环境、气候环境与社会经济因 素共同作用的结果,已成为人地耦合系统脆弱性的 热点研究内容 ${ }^{[6-10]}$ 。相关研究在全球变化、可持续性 科学以及地理学等学科领域引起广泛关注与响应, 因其具有预警和减缓干旱影响的作用,已经成为干 旱半干旱地区制定干旱减缓和预防政策的首要环节 ${ }^{[1]}$ 。

干旱脆弱性在不同地理单元的时空演变规律 受到地理学的广泛关注。国外学者已分别从国家、 区域、城市等不同地理空间尺度评价干旱脆弱性的 时空特征 ${ }^{[6,7,12-14]}$ 。随着干旱脆弱性研究的不断深
人, 诸多学者开始关注干旱对乡村人地系统的干扰 与影响。作为乡村人地系统应对干旱的直接主体, 乡镇(社区) 是防灾减灾管理的基本单元,也是农村 经济的主体和农村各项事业的中心地 ${ }^{[15]}$, 已在社会、 经济和环境等方面受到干旱的负面影响 ${ }^{[16]}$, 严重威 胁乡村人地系统的可持续发展。国外在社区尺度 进行了多项干旱脆弱性案例研究。Wittrock等针对 加拿大南萨斯喀彻温河流域乡村社区进行干旱脆 弱性的评估与适应策略分析 ${ }^{[16]}$; Young 等以智利北 部埃尔基河流域依赖灌溉生存的乡村社区为例, 分 析水资源短缺导致的暴露与敏感性问题 ${ }^{[17]}$; Nelson 等建立自然灾害脆弱性测定模型, 利用降水量指标 评价澳大利亚乡村社区对气候变化的脆弱性 ${ }^{[18]}$ 。而 纵观国内现有相关文献发现: 多数研究集中在区 域、流域和城市等空间地理单元,包括中国南方地

收稿日期: 2017-04-10 ; 修订日期: 2017-08-05

基金项目: 国家自然科学基金项目(41571163)。

作者简介: 石育中, 男, 甘肃陇南人,博士生, 研究方向为人地耦合系统脆弱性与区域可持续发展。E-mail : syz19880919@126.com 通讯作者: 杨新军, E-mail : yangxj@nwu.edu.cn 


\section{2 研究区概况、数据来源与研究方法}

\section{1 研究区概况}

榆中县地处黄土高原西部, 隶属于甘肃省中 部, 位于 $103^{\circ} 50^{\prime} \mathrm{E}-104^{\circ} 34^{\prime} \mathrm{E}, 35^{\circ} 34^{\prime} \mathrm{N}-36^{\circ} 26^{\prime} \mathrm{N}$, 海拔 $1430 \sim 3670 \mathrm{~m}$, 面积 $3301.64 \mathrm{~km}^{2}$, 地势南高北低, 中部 凹, 呈马鞍形, 可分为北部干旱山区、南部高寒二阴 山区和中部川塬河谷区。榆中县地处季风气候区 与非季风气候区的过渡地带, 是典型的温带半干旱 大陆性季风气候区 ${ }^{[34]} 。 1960-2015$ 年, 年平均气温 $6.9^{\circ} \mathrm{C}$, 年平均降水 $386 \mathrm{~mm}$ (如图 1)。榆中县现辖青 城镇、金崖镇、夏官营镇、城关镇、定远镇、和平镇、 甘草店镇、高崖镇、小康营乡、连搭乡、来紫堡乡、三 角城乡、银山乡、马坡乡、新营乡、清水驿乡、龙泉 乡、韦营乡、中连川乡、贡井乡、园子岔乡、上花岔 乡、哈岘乡共 8 镇 15 乡(如图 2),268 个行政村,2015 年末, 榆中县域户籍人口为 44.67 万人, 其中, 城镇 户籍人口为 9.11 万人,农业户籍人口 35.56 万人。

干旱缺水一直是黄土高原人地系统最主要的 外部干扰因素 ${ }^{[1]}$ 。随着干旱化趋势的不断增强,榆 中县近年来一直处于干旱高发区 ${ }^{[35]}$, 因其生态系统 脆弱与人类活动的扰动, 导致生态环境恶化和农民 贫困问题严重,致使乡村人地系统脆弱性加剧。榆 中县内地势复杂, 北部与南部为山区, 中部为河谷 盆地,干旱程度、基础设施和灌溉条件存在差异。 选择榆中县作为研究区, 在揭示乡村人地系统脆弱 性时间变化规律与空间异质性,促进乡村人地系统 可持续发展方面具有典型意义。

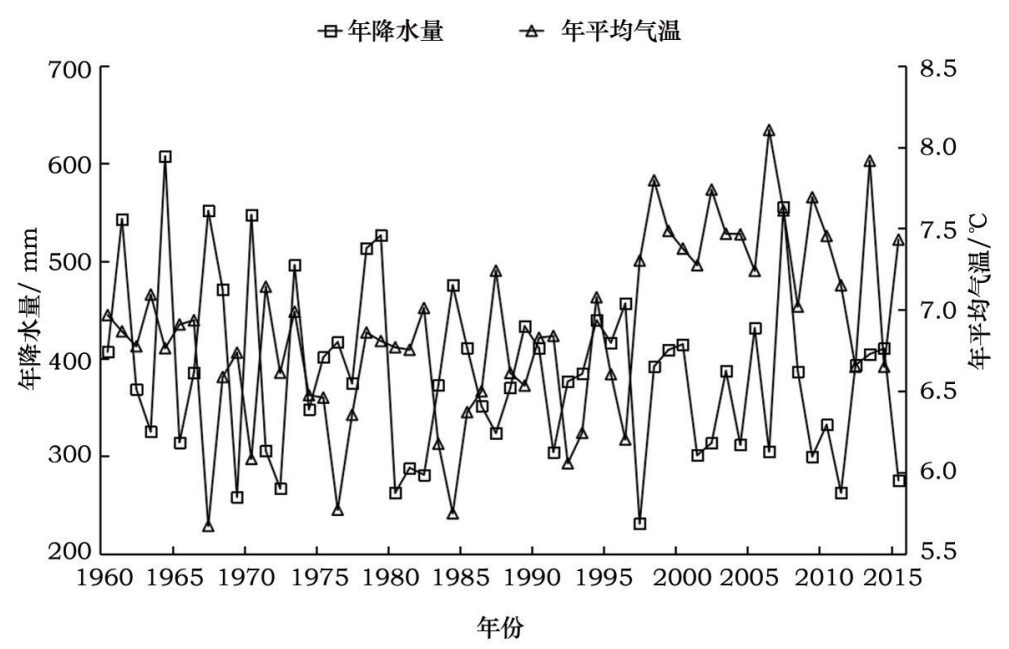

图 1 榆中县气候指标

Figure 1 Meteorological condition of Yuzhong County 


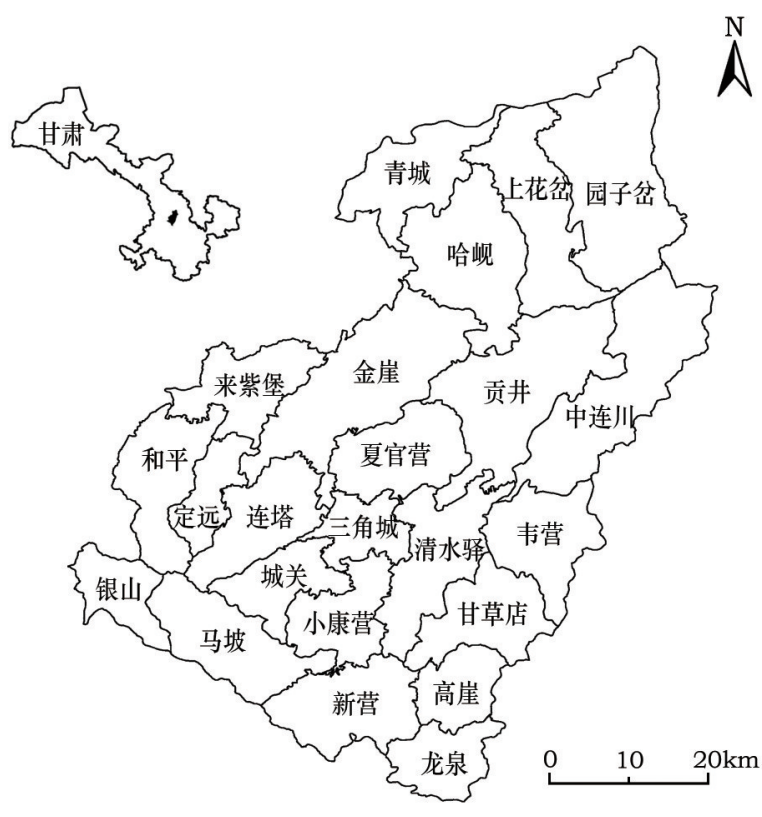

图 2 榆中县地理位置

Figure 2 Location of Yuzhong County

\section{2 数据来源}

本文数据包括气象数据、遥感数据和统计数据 三部分。其中,气象数据源自中国气象科学数据共 享服务网 ${ }^{[36]}$ 和榆中县气象局, 主要包括榆中县气象 站点 1960-2015 年的年降水量和年平均气温和榆 中县各乡镇 2002-2015 年的年降水量和年平均气 温; 坡度数据由 DEM 数据 (空间分辨率 $30 \mathrm{~m}$ ) 提取 所得, DEM 数据下载于地理数据云平台 ${ }^{[37]} ; \mathrm{NDVI}$ 数 据来自于美国地质勘探局 ${ }^{[38]}$ MODIS 的 2002-2015 年 MOD13Q1 数据, 空间分辨率为 $250 \mathrm{~m}$, 时间分辨 率为 $16 \mathrm{~d}$,并进行格式转换和投影转换以及去除 云、雾和太阳高度角等处理; 统计数据源自《榆中县 统计提要 (2015 年)》和《榆中县农业统计年报 （2002-2015 年)》,于 2016年 7 月实地调研,由榆中 县统计部门提供所得。

\section{3 研究方法}

\subsection{1 指标体系构建}

干旱脆弱性是人地系统对干旱的敏感性, 以及 由于缺乏应对能力而使系统易于遭受损失的性质 和状态, 由暴露度、敏感性和适应能力构成 ${ }^{[6-8,21]}$ 。基 于干旱脆弱性评价框架 (Drought Vulnerability Assessment $)^{[8]}$, 依据干旱脆弱性相关文献和实地情 况,综合考虑干旱相关指标、干旱产生的直接或潜
在影响以及乡镇应对干旱的生计条件, 分别从暴露 度、敏感性和适应能力三个维度构建干旱脆弱性指 标体系。具体构建过程如下:

暴露度 (Exposure) 是气候条件变化对研究单元 造成的压力, 可用气候变化相关指标表征如气温、 降水等 ${ }^{[39]}$ 。选择年降水量 $(2002-2015$ 年)、年平均 气温(2002-2015 年)和坡度 3 项指标来表征暴露 度。其中, 年降水量和年平均气温直接影响干旱程 度 ${ }^{[11-14,40]}$, 坡度决定土壤持水能力, 影响干旱的威胁 程度 ${ }^{[39]}$

敏感性 (Sensitivity) 是气候事件 (Climate Event)和社会经济系统的相互作用,用来表征系统 对扰动的敏感性 (Susceptibility) ${ }^{[39]}$ 。选择干旱影响 面积(受灾面积)、人口密度、农业人口比例、NDVI、 粮食产量、农业GDP 比例 6 项指标来表征敏感性。 干旱频率和强度直接影响干旱影响面积的变化 ${ }^{[1,14]}$; 粮食产量和农业 GDP 比例对干旱敏感,粮食产量和 农业 GDP 比例越高, 潜在损失越大, 则脆弱性越大; 农业人口对干旱较为敏感,农业人口比例越高, 则 脆弱性越大 ${ }^{[1,40]}$; NDVI 对降水量敏感, NDVI 越高, 潜在影响越大, 则脆弱性越大 ${ }^{[1,14]}$; 而人口密度与干 旱脆弱性具有正相关性,高人口密度导致资源和环 境压力增加, 直接影响生态环境安全 ${ }^{[1]}$ 。

适应能力 (Adaptive Capacity) 是系统对气候环 境扰动的适应 (Accommodate) 和恢复 (Recover) 能 力 ${ }^{[39]}$ 。参考相关文献, 考虑到数据的可获得性和实 地情况，选择农民纯收人、住房面积、人均耕地面 积、高中以上教育人数、农业科技人员、灌溉设施数 量 (水窄和机井)、通电户数、牲畜数量、人均 GDP、 有效灌溉面积 10 项指标来表征。灌溉设施与有效 灌溉面积直接影响干旱的缓解能力; 人均耕地 (自 然资本) 与住房面积及通电户数 (物质资本) 作为重 要的适应资源, 是抵抗干旱扰动的基础能力, 而饲 养牲畜作为维持生计的重要方式, 是提高适应能力 的有效途径。高中以上教育人数和农业科技人员 作为人力资本, 决定着劳动力质量和生产潜力; 人 均 GDP 和农民纯收人作为重要的金融资本, 是适应 能力的关键因素 ${ }^{[11-14,40,41]}$ 。

2.3.2 指标权重赋值

诸多研究采用相同权重确定指标权重,然而忽 
相乘所得,具体计算公式如下：

$$
\begin{aligned}
& E I=\sum_{j=1}^{n} w_{j} \times X_{j} \\
& S I=\sum_{j=1}^{n} w_{j} \times X_{j} \\
& A C I=\sum_{j=1}^{n} w_{j} \times X_{j} \\
& D V I=E I+S I-A C I
\end{aligned}
$$

式中 $D V I$ 为干旱脆弱性指数; $w_{j}$ 为指标权重; $X_{j}$ 为 指标标准值; $E I$ 为暴露度指数; $S I$ 为敏感性指数; $A C I$ 为适应能力指数。

\subsubsection{Getis-Ord $\mathrm{G}^{*}$}

采用 Getis 和 Ord提出的局部 $\mathrm{G}^{*}$ 统计量, 公式为:

$$
G_{i}^{*}=\frac{\sum_{j} w_{i j} x_{j}-\bar{x}^{*} \sum_{j} w_{i j}}{S^{*} \sqrt{\left(n \sum_{j} w_{i j}^{2}\left(\sum_{j} w_{i j}\right)^{2}\right) /(n-1)}}
$$

式中 $i$ 为指标层指标; $j$ 为维度指标; $S_{i} 、 S_{i j}$ 为指标 标准化值; $P_{i j}$ 为矩阵 $; e_{j}$ 为指标的信息熵; $g_{j}$ 为差 异性系数; $w_{j}$ 为指标权重。

\subsection{3 干旱脆弱性指数}

干旱脆弱性指数由暴露度指数、敏感性指数和

\begin{tabular}{|c|c|c|c|}
\hline & 维度 & 指标层 & 权重 \\
\hline \multirow[t]{19}{*}{ 干旱脆弱性 } & 暴露度 & 年均降水量 $(2002$-2015 年) $/ \mathrm{mm}$ & 0.343 \\
\hline & & 年平均气温 $(2002-2015$ 年 $) /{ }^{\circ} \mathrm{C}$ & 0.320 \\
\hline & & 坡度/ & 0.337 \\
\hline & 敏感性 & 干旱影响面积/m² & 0.210 \\
\hline & & 人口密度 $/\left(\right.$ 人 $\left./ \mathrm{km}^{2}\right)$ & 0.179 \\
\hline & & 农业人口比例/\% & 0.167 \\
\hline & & NDVI & 0.155 \\
\hline & & 粮食产量/t & 0.152 \\
\hline & & 农业 GDP 比例/\% & 0.138 \\
\hline & 适应能力 & 农民纯收人/元 & 0.194 \\
\hline & & 住房面积 $/ \mathrm{m}^{2}$ & 0.109 \\
\hline & & 人均耕地面积 $/ \mathrm{hm}^{2}$ & 0.108 \\
\hline & & 高中以上教育人数/人 & 0.099 \\
\hline & & 农业科技人员/人 & 0.098 \\
\hline & & 灌溉设施数量/个 & 0.095 \\
\hline & & 通电户数/户 & 0.092 \\
\hline & & 牲畜数量/头 & 0.081 \\
\hline & & 人均 GDP/元 & 0.072 \\
\hline & & 有效灌溉面积 $/ \mathrm{hm}^{2}$ & 0.052 \\
\hline
\end{tabular}
适应能力指数组成 ${ }^{[8]}$, 其中暴露度指数、敏感性指数 和适应能力指数由极差标准化所得指标值与权重

表 1 榆中县干旱脆弱性指标体系

Table 1 Indicators system of drought vulnerability in Yuzhong county
式中 $\bar{x}^{*}=\sum_{j} x_{j} / n, S^{*}=\sqrt{\sum_{j} x_{j}^{2}-\bar{x}_{j}^{2}}, n$ 为区域单元 数; $x_{j}$ 为区域单元 $j$ 的属性值; $w_{i j}$ 为区域单元 $i$ 和 $j$ 之间的距离权。 $G^{*}$ 统计量实质为显著性统计量, 高 $G^{*}$ 值表明为相似高值空间聚集, 即热点地区; 低 $G^{*}$ 值表明为相似低值空间聚集, 即冷点地区; 接近 0 时, 表示没有明显的空间相关性 ${ }^{[2]}$ 。

\section{3 结果及分析}

如图 3 所示, 2002-2015 年, 榆中县干旱脆弱 性指数呈波动式变化,阶段性升降明显。其中, 2012 年干旱脆弱性指数为 0.470 ,干旱脆弱程度最 低, 2014 年干旱脆弱性指数为 0.566 ,干旱脆弱程度 最高。就暴露度指数而言, 2002-2015 年, 暴露度 指数变化不明显, 说明暴露程度趋于稳定; 就敏感 性指数而言, 2002-2015 年,敏感性指数呈波动式 上升趋势, 由 2002 年的 0.380 增加到 2015 年的 0.405 , 表明干旱的敏感性趋于阶段性增强,但增强 趋势较小; 就适应能力指数而言, 2002-2015年,适 应能力指数变化明显,但变化趋势较小,说明适应 能力变化较小。经对比发现,干旱脆弱性指数与敏 感性指数变化趋势相似。原因在于:干旱脆弱性指 数与暴露度指数和敏感性指数成正线性关系, 且暴 露度指数变化较小, 导致两者变化趋势趋同。

如表 2 所示, 2002-2015 年, 榆中县各乡镇干

\section{1 干旱脆弱性指数时间趋势变化}




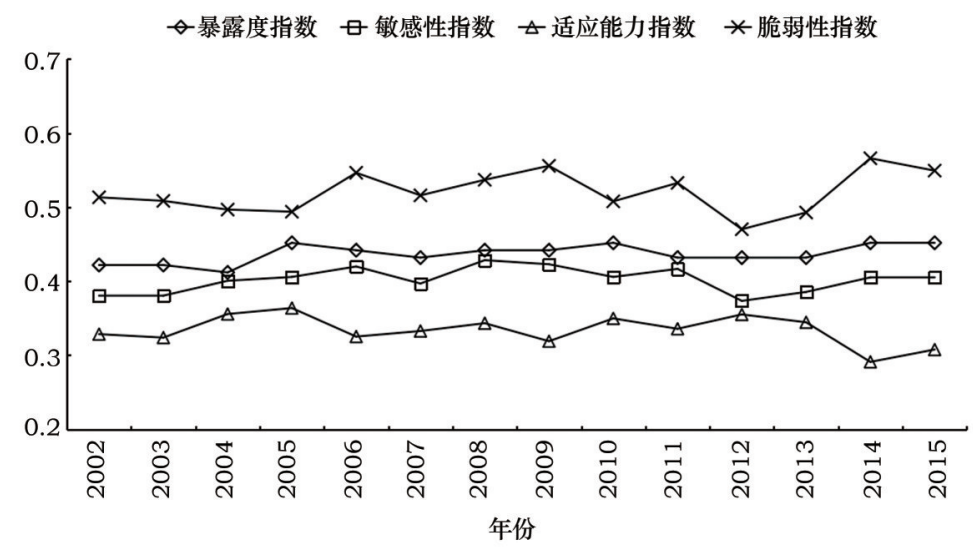

图 $32002-2015$ 年榆中县干旱脆弱性指数

Figure 3 Drought vulnerability index in Yuzhong County from 2002 to 2015

表 $22002-2015$ 年榆中县各乡镇干旱脆弱性指数

Table 2 Drought vulnerability index of towns in Yuzhong County from 2002 to 2015

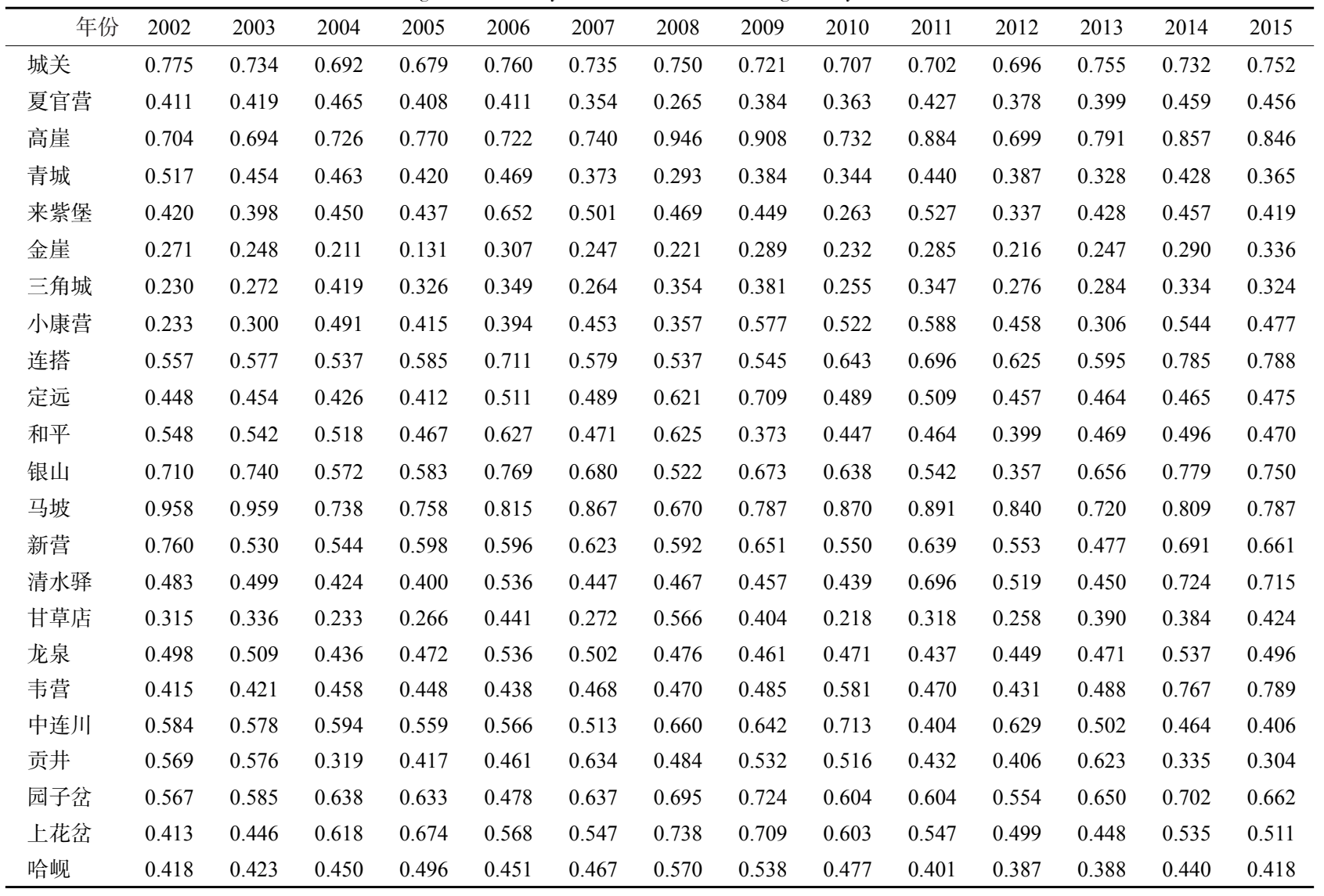

旱脆弱性指数呈波动变化趋势。其中, 城关干旱脆 弱指数变化幅度最小, 最低值为 0.679 ,最高值为 0.775 , 干旱脆弱性程度较为稳定; 银山干旱脆弱性 指数变化范围幅度最大, 最低值为 0.357 ,最高值为 0.779 , 干旱脆弱性指数变化趋势明显, 干旱脆弱程 度最不稳定。此外,通过计算 2002-2015 年榆中县
各乡镇干旱脆弱性指数的算数平均值,干旱脆弱性 指数由低到高分别为金崖、三角城、甘草店、夏官 营、青城、来紫堡、小康营、哈岘、龙泉、定远、和平、 贡井、韦营、清水驿、上花岔、中连川、新营、园子岔、 连搭、银山、城关、高崖和马坡, 其中, 金崖干旱脆弱 性指数均值最低为 0.252 , 马坡干旱脆弱性指数均 
2015 年, 冷点-次冷区域主要分布于榆中县中部盆

\section{2 干旱脆弱性空间格局演变}

局域空间关联指数 Getis-Ord G*可以反映局部 空间聚集性,能够有效地表现热点区域的空间格局 演变 ${ }^{[42]}$ 。因此,依据相关文献,选择起止时间与中间 时间节点即 2002 年、2008 年和 2015 年, 通过 GIS 10.1 计算榆中县 2002 年、 2008 年和 2015 年 $G_{i}$ 统计 量, 并运用 Jenks 最佳自然断裂法将其由高到低分 成四类,生成2002-2015 年榆中县干旱脆弱性空间 格局热点演变图(图4)。

如图 4 所示, 干旱脆弱性热点区域总体格局呈 现“南-北热中部冷”的空间特征,具有明显的地理集 聚特征。2002年、2008年和 2015 年,热点-次热区域 主要分布于榆中县南北部山区, 且局部稳定。处于 该区域的乡镇包括上花岔、园子岔、贡井、中连川、 哈岘、和平、定远、城关、高崖、马坡、新营和银山。 原因在于:南北部山区降雨量少,海拔较高且地形 复杂,生计方式主要以种植抗旱性经济作物 (百合, 药材和玉米等)为主,铺设地膜为主要的抗旱措施, 由于交通可达性低且距离县中心较远,农民收人较 低,适应能力有限,因此集中表现为干旱脆弱性较 高的空间特征。其中, 龙泉一直处于热点区域, 哈 岘、贡井、中连川、和平、城关和小康营一直处于次 热区域,集聚特征较为稳定。2002 年、2008 年 和 地, 且格局呈动态变化特征,处于该区域的乡镇包 括金崖、夏官营、清水驿、来紫堡和青城。原因在 于: 中部盆地灌溉设施便利, 经济作物以蔬菜种植 为主, 经济效益较好, 且距离县中心较近,打工兼农 成为主要生计方式,农民收人较高, 适应能力较高, 但由于距离县中心较近, 不确定因素增加, 导致地 理集聚格局具有不稳定性。而青城虽位于北山,但 距离白银市较近, 有一定规模的灌溉设施, 且以大 棚果蔬种植为主,农民收人较高, 适应能力较强。

\section{3 干旱脆弱性类型}

为了区分不同乡镇的干旱脆弱程度, 根据干旱 脆弱性指数分类标准, 将干旱脆弱性指数 (DVI) 在 $(0,1)$ 范围划分为: 高 $(0.666 \leqslant D V I<1)$ 、中 $(0.333 \leqslant$ $D V I<0.666)$ 、低 $(0<D V I<0.333)$ 三个等级 ${ }^{[21]}$ 。依 据相关文献，选择起止时间与中间时间节点即 2002 年、2008 年和 2015 年, 对榆中县干旱脆弱性进行 分类。

如图 5 所示, 2002 年, 处于高干旱脆弱类型的 乡镇分别为马坡、城关、新营、银山和高崖, 占榆中 县乡镇总数的 $22 \%$; 处于低干旱脆弱类型的乡镇分 别为甘草店、金崖、小康营和三角城,占榆中县乡镇 总数的 $17 \%$; 其他乡镇处于中干旱脆弱性类型, 占 榆中县乡镇总数的 $61 \%$ 。2008 年,处于高干旱脆弱

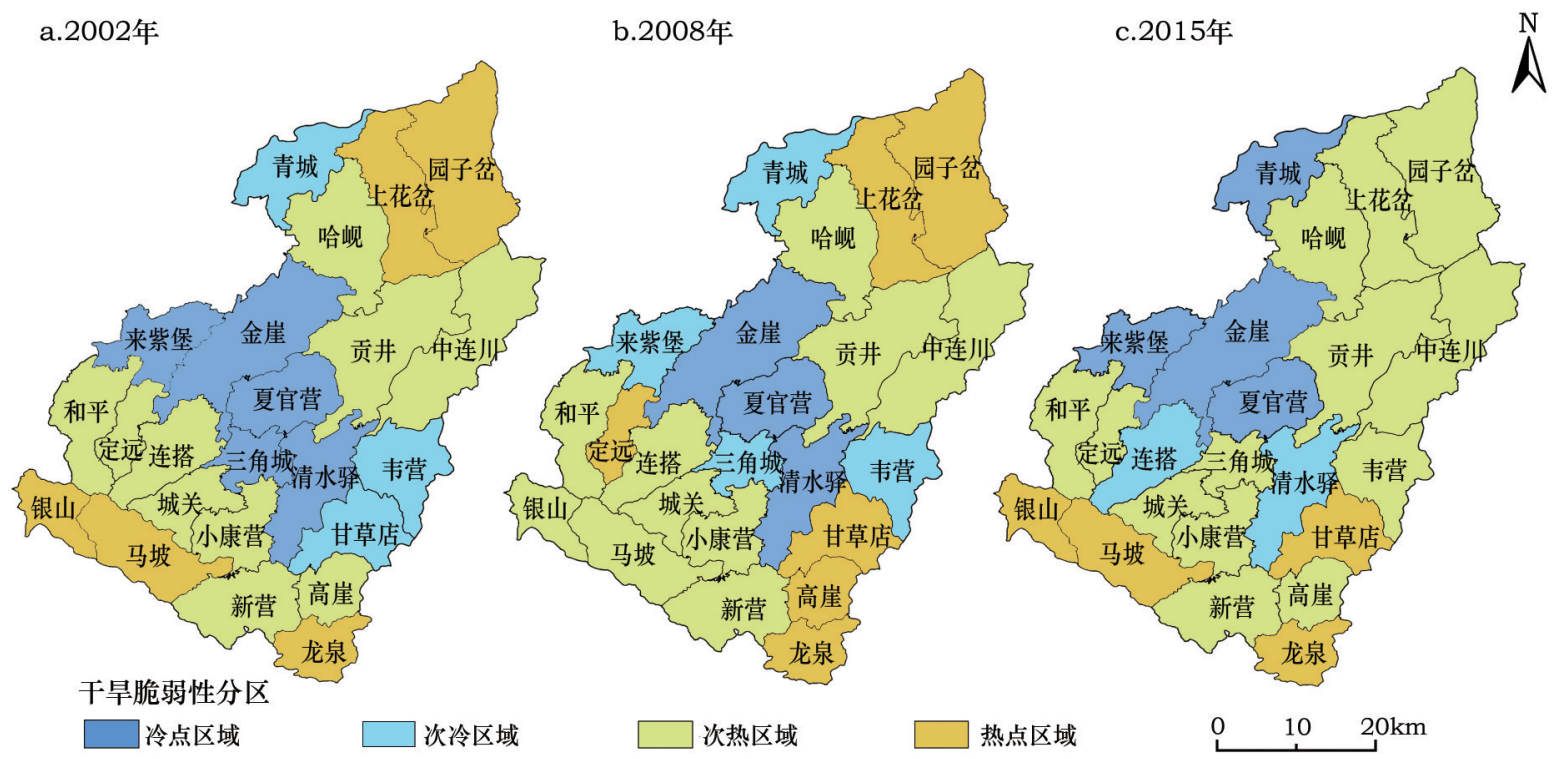

图 4 榆中县干旱脆弱性时空演化

Figure 4 Spatial-temporal evolution of drought vulnerability in Yuzhong County 


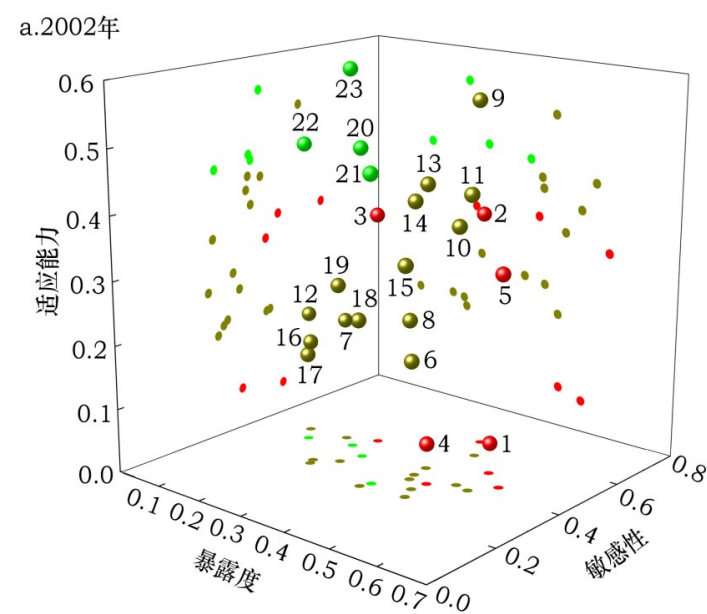

1 马坡 2 城关 3 新营 4 银山 5 高崖 6 中连川 7 贡井 8 园子岔 9 连搭 10 和平 11 青城 12 龙泉 13 清水驿 14 定远 15来紫堡 16 哈峴 17 韦营 18 上花岔 19 夏官营 20 甘草店 21 金崖 22小康营 23 三角城 b.2008年

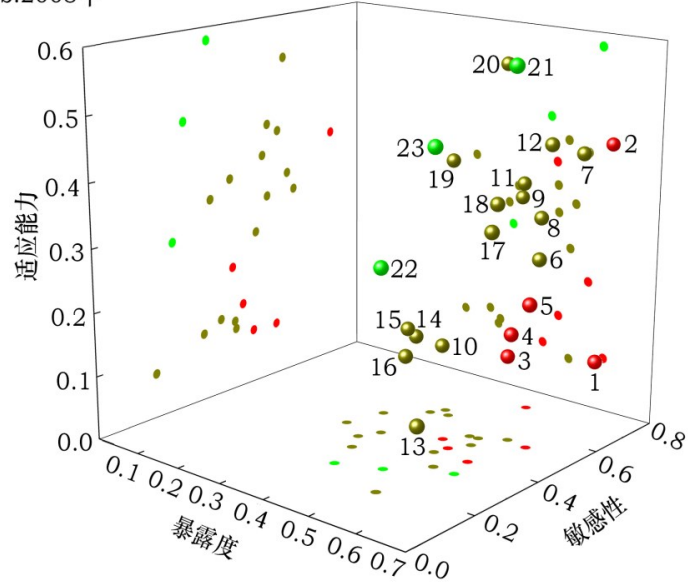

1 高崖 2 城关 3 上花岔 4 园子岔 5 马坡 6 中连川 7 和平 8 定远 9 新营 10 哈岘 11 甘草店 12连搭 13 银山 14贡井 15龙泉 16韦营 17

来紫堡 18 清水驿 19 小康营 20 三角城 21 青城 22 夏官营 23 金崖 c. 2015 年

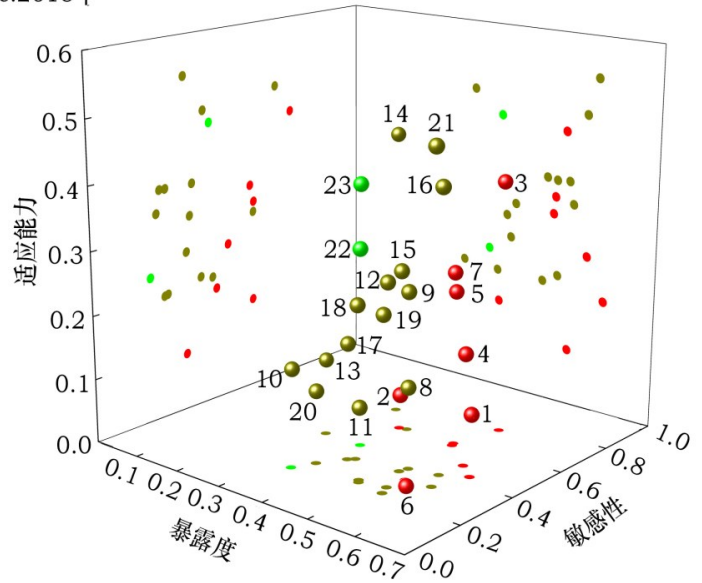

1 高崖 2 韦营 3 连搭 4 马坡 5 城关 6 银山 7 清水桻 8 园子岔 9 新营 10 贡井 11 上花岔 12 中连川 13 龙泉 14 小康营 15 定远 16 和平 17夏官营 18甘草店 19来紫堡 20哈岘 21 青城 22金崖 23三角城 脆弱程度 - 高 中 低

图 5 榆中县干旱脆弱性类型

Figure 5 Types of drought vulnerability in Yuzhong County
类型的乡镇分别为高崖、城关、上花岔、园子岔和马 坡, 占榆中县乡镇总数的 $22 \%$,与 2002 年所占比例 相同; 处于低干旱脆弱类型的乡镇分别为青城、夏 官营和金崖, 占榆中县乡镇总数的 $13 \%$, 比 2002 年 减少 $4 \%$; 其他乡镇处于中干旱脆弱性类型, 占榆中 县乡镇总数的 $65 \%$, 比 2002 年增加 $4 \%$ 。2015 年, 处于高干旱脆弱类型的乡镇分别为高崖、韦营、连 搭、马坡、城关、银山和清水驿, 占榆中县乡镇总数 的 $30 \%$, 比 2008 年增加 $8 \%$; 处于低脆弱类型的乡 镇分别为金崖和三角城,占榆中县乡镇总数的 $9 \%$, 比 2008 年减少 $4 \%$; 其他乡镇处于中干旱脆弱性类 型, 占榆中县乡镇总数的 $61 \%$, 比 2008 年减少 $4 \%$ 。由此可见,2002-2015年,不同脆弱类型的乡 镇数量由高到低分别为中脆弱 $>$ 高脆弱 $>$ 低脆弱, 高干旱脆弱乡镇数量增加趋势明显, 且金崖一直处 于低干旱脆弱程度, 高崖、城关和马坡一直处于高 干旱脆弱程度。其中, 高干旱脆弱类型增加的乡镇 位于北部和南部山区, 主要由中脆弱类型转变为高 脆弱性类型所致,转变的原因在于干旱暴露度增 加,干旱影响范围和程度增大, 由于适应能力提高 途径有限, 使得适应能力难以提升, 导致干旱脆弱 性加强。

\section{4 干旱脆弱性影响因素}

干旱脆弱性由暴露度、敏感性和适应能力共同 决定。由于干旱脆弱性与暴露度、敏感性和适应能 力存在线性关系, 因此,干旱脆弱性指数的大小取 决于暴露度、敏感性和适应能力 3 个维度下的指标 及其权重, 指标权重越大, 影响干旱脆弱性指数的 程度越大, 反之影响程度越小。

就整体影响因子而言, 影响系数(如表3)由高

\section{表 3 干旱脆弱性影响因子及影响系数}

Table 3 The influence factors and coefficients of drought vulnerability

\begin{tabular}{lc}
\hline 影响因子 & 影响系数 \\
\hline 年降水量 & 0.114 \\
坡度 & 0.112 \\
年平均气温 & 0.107 \\
干早影响面积 & 0.070 \\
农民纯收人 & 0.065 \\
人口密度 & 0.060 \\
农业人口比例 & 0.056 \\
\hline
\end{tabular}

注:影响系数由指标权重归一化处理所得,小于 0.052 的指标, 影响程度较小,可忽略不计。 
乡镇热点区域趋于稳定。

\section{2 讨论}

干旱脆弱性具有地方特性(Placed-Specific), 亟 需从全球、国家和区域尺度向地方尺度延伸,进行 “自上而下”的深人研究 ${ }^{[4]}$ 。地方尺度的可持续性问 题历来是地理学关注的主要问题,需要更多地方尺 度的实证案例的充实和对比 ${ }^{[6,10,43]}$ 。不同时空尺度 的脆弱性研究是深刻认识、科学评价和有效管理灾 害时空风险必须关注的重要学科问题 ${ }^{[4]}$ 。与此同 时, 未来的农业与乡村地理学研究将越来越注重研 究尺度的细化, 如乡村社区对环境不确定性的顺应 能力 ${ }^{[45]}$, 因此, 选择乡村人地系统乡镇 (社区) 分析不 同时空尺度的干旱脆弱性,试图揭示气候变化对乡 村人地系统的影响, 为人地系统脆弱性研究提供新 的视角。

干旱脆弱性分析框架具有一定的局限性。一 方面,标准化方法、权重方法和干旱脆弱性指数计 算公式导致结果具有不确定性 ${ }^{[46]}$, 可运用不确定评 价 (Uncertainty Assessment)、鲁棒性分析 (Robustness Analysis)、不确定与敏感性分析 (Uncertainty and Sensitivity analysis), 增加干旱脆弱性指数的科 学性和可信性 ${ }^{[47,48]}$ 。另一方面, 针对如何降低干旱 脆弱性和增加系统恢复能力, 乡村人地系统应对干 旱的适应机理等重要问题,干旱脆弱性的解释力度 不足。恢复力理论试图分析系统适应变化和干扰 的能力, 为理解周围世界和管理自然资源提供了一 种新的认知方式 ${ }^{[49]}$, 为乡村人地系统可持续性研究 提供新的思路。

\section{参考文献 (References) :}

[1] Wu D, Yan D H, Yang G Y, et al. Assessment on agricultural drought vulnerability in the Yellow River basin based on a fuzzy clustering iterative model[J]. Natural Hazards, 2013, 67 (2): 919-936.

[2] 邱海军, 曹明明, 郝俊卿, 等. 1950-2010年中国干旱灾情频率规模关系分析 [J]. 地理科学, 2013, 33(5): 576-580. [Qiu H J, Cao M M, He J Q, et al. Relationship between frequency and magnitude of drought damage in China in 1950- 2010[J]. Scientia Geographica Sinica, 2013,33(5):576-580.]

[3] 何斌, 武建军, 吕爱锋. 农业干旱风险研究进展 [J]. 地理科学进 展, 2010, 29(5): 557-564. [He B, Wu J J, Lv A F. New advances 
in agricultural drought risk study[J]. Progress in Geography, 2010,29(5):557-564.]

[4] 程静, 陶建平. 全球气候变暖背景下农业干旱灾害与粮食安 全: 基于西南五省面板数据的实证研究 [J]. 经济地理, 2010,30 (9) : 1524-1528. [Cheng J, Tao J P. Agricultural drought disaster and food security under the background of global warming: based on panel data of five provinces of southwest China[J]. Economic Geography, 2010,30(9):1524-1528.]

[5] 高超, 金凤君, 雷军, 等. 干早区绿洲城市经济系统脆弱性评价 研究 [J]. 经济地理, 2012, 32(8): 43-49. [Gao C, Jin F J, Lei J, et al. Vulnerability assessment of economic system of Oasis cities in arid area[J]. Economic Geography, 2012, 32(8): 43-49.]

[6] Naumann G, Barbosa P, Garrote L, et al. Exploring drought vulnerability in Africa: an indicator based analysis to inform early warning systems[J]. Hydrology \& Earth System Sciences, 2013, 18(5): 12217-12254

[7] Thomas T, Jaiswal R K, Galkate R, et al. Drought indicatorsbased integrated assessment of drought vulnerability: a case study of Bundelkhand droughts in central India[J]. Natural Hazards, 2016, 81 (3): 1627-1652.

[8] Tánago I G, Urquijo $\mathrm{J}$, Blauhut $\mathrm{V}$, et al. Learning from experience: a systematic review of assessments of vulnerability to drought[J]. Natural Hazards, 2015, 80(2): 951-973.

[9] Balochistan, Pakistan A M, Routray J K, et al. Determinants of farmers' choice of coping and adaptation measures to the drought hazard in northwest Balochistan, Pakistan[J]. Natural Hazards, 2014, 73(3): 1451-1473.

[10] Lei Y, Wang J, Yue Y, et al. Rethinking the relationships of vulnerability, resilience, and adaptation from a disaster risk perspective[J]. Natural Hazards, 2014, 70 (1): 609-627.

[11] Piya L, Joshi N P, Maharjan K L. Vulnerability of Chepang households to climate change and extremes in the Mid-Hills of Nepal[J]. Climatic Change, 2016, 135(3-4): 521-537.

[12] Mildrexler D, Yang Z, Cohen W B, et al. A forest vulnerability index based on drought and high temperatures[J]. Remote Sensing of Environment, 2015, 173: 314-325

[13] Thomas D S K, Wilhelmi O V, Finnessey T N, et al. A comprehensive framework for tourism and recreation drought vulnerability reduction[J]. Environmental Research Letters, 2013, 8(4): 575-591.

[14] Pei W, Fu Q, Liu D, et al. Assessing agricultural drought vulnerability in the Sanjiang Plain based on an improved projection pursuit model[J]. Natural Hazards, 2016, 82(1): 683-701.

[15] 丁志伟, 张改素,王发曾. 郑州都市区镇域经济差异的空间分 析 [J]. 经济地理, 2013, 33 (7): 29-35. [Ding Z W, Zhang G S, Wang F C. The spatial analysis on towns' economic differences in Zhengzhou Metropolitan Area[J]. Economic Geography, 2013,33(7):29-35.]
[16] Wittrock V, Kulshreshtha S N, Wheaton E. Canadian prairie rural communities: their vulnerabilities and adaptive capacities to drought[J]. Mitigation and Adaptation Strategies for Global Change, 2011, 16(3):267-290.

[17] Young G, Zavala H, Wandel J, et al. Vulnerability and adaptation in a dryland community of the Elqui Valley, Chile[J]. Climatic Change, 2010, 98(1): 245-276.

[18] Nelson R, Kokic P, Crimp S, et al. The vulnerability of Australian rural communities to climate variability and change: part II- Integrating impacts with adaptive capacity[J]. Environmental Science \& Policy, 2010, 13(1): 18-27.

[19] 王莺, 王静, 姚玉璧, 等. 基于主成分分析的中国南方干旱脆弱 性评价[J]. 生态环境学报, 2014, 23(12): 1897-1904. [Wang Y, Wang J, Yao Y B, et al. Evaluation of drought vulnerability in Southern China based on principal component analysis[J]. Ecology and Environmental Sciences, 2014, 23 (12) : 1897 1904.]

[20] 侯光良, 肖景义, 李生梅. 基于气候变化的干旱脆弱性评价-以 青海东部为例 $[J]$. 自然灾害学报, 2012,21(2): 165-170. [Hou G L, Xiao J Y, Li S M. Vulnerability assessment of drought based on climate change: a case study of eastern Qinghai Province[J]. Journal of natural disasters, 2012, 21 (2) : 165170.]

[21] 喻忠否, 杨新军, 石育中. 关中地区城市干旱脆弱性评价[J]. 资 源科学, 2012, 34 (3) : 581-588. [Yu Z L, Yang X J, Shi Y Z. Evaluation of urban vulnerability to drought in Guanzhong area [J]. Resources Science, 2012,34(3): 581-588.]

[22] 李梦娜, 钱会, 乔亮. 关中地区农业干旱脆弱性评价[J]. 资源科 学, 2016, 38 (1): 166-174. [Li M N, Qian H, Qiao L. Evaluation of agricultural vulnerability to drought in Guanzhong Area[J]. Resources Science, 2016,38(1): 166-174.]

[23] 胡颖颖,玉米提・哈力克, 塔依尔江・艾山, 等. 新疆 2001-2010 年农业气候干旱脆弱性分析 [J]. 中国沙漠, 2014, 34(1): 254259. [Hu Y Y, Halik U, Aishan T, et al. Vulnerability to drought on agriculture in Xinjiang during 2001-2010[J]. Journal of Desert Research,2014,34(1):254-259.]

[24] 周利光, 杜风莲, 张雪峰, 等. 草原畜牧业对干旱的脆弱性评 估-以内蒙古锡林郭勒草原为例 [J]. 生态学杂志, 2014, 33(1): 259-268. [Zhou L G, Du F L, Zhang X F, et al. The vulnerability assessment of grassland livestock industry to drought: a case study in pasture of Xilingol, Inner Mongolia[J]. Chinese Journal of Ecology, 2014, 33(1):259-268.]

[25] 於琍. 干旱对生态系统脆弱性的影响研究-以长江中下游地区 为例 $[J]$. 长江流域资源与环境, 2014, 23(7): 1021-1028. [Yu L. Assessing on ecosystem vulnerability to drought: the case study of the middle and lower reaches of the Yangtze river[J]. Resources and Environment in the Yangtze Basin, 2014, 23 (7): 1021-1028.] 
[26] 曹永强, 马静, 李香云, 等. 投影寻踪技术在大连市农业干旱脆 弱性评价中的应用 [J]. 资源科学, 2011, 33 (6) : 1106-1110, [Cao Y Q, Ma J, Li X Y, et al. Application of the projection pursuit technique in assessment of agricultural drought vulnerability in Dalian[J]. Resources Science, 2011,33(6): 1106-1110.]

[27] 康永辉, 解建仓, 黄伟军, 等. 农业干旱脆弱性模糊综合评价 [J]. 中国水土保持科学, 2014, 12(2): 113-120. [Kang Y H, Xie $\mathrm{J}$ C, Huang $\mathrm{W} \mathrm{J}$, et al. Fuzzy comprehensive evaluation of agricultural drought vulnerability[J]. Science of Soil and Water Conservation, 2014, 12(2): 113-120.]

[28] 赵一飞, 邹欣庆, 张勃, 等. 黄土高原甘肃区降水变化与气候指 数关系 $[J]$. 地理科学, 2015, 35(10): 1325-1332. [Zhao Y F, Zou X Q, Zhang B, et al. Precipitation variation in association with climate indices in Loess Plateau of Gansu Province, Northwest China[J]. Scientia Geographica Sinica, 2015, 35 (10): 1325-1332.]

[29] 赵安周, 刘宪锋, 朱秀芳, 等. 1965-2013 年黄土高原地区极端 气温趋势变化及空间差异 [J]. 地理研究, 2016, 35 (4): 639652. [Zhao A Z, Liu X F, Zhu X F, et al. Trend variations and spatial difference of extreme air temperature events in the Loess Plateau from 1965 to 2013[J]. Geographical Research, 2016, 35 (4): 639-652.]

[30] 姚玉璧, 王润元, 王劲松, 等. 中国黄土高原春季干早 10a 际演 变特征 $[J]$. 资源科学, 2014, 36(5): 1029-1036. [Yao Y B, Wang $\mathrm{R}$ Y, Wang J S, et al. Decadal variation in spring drought for the Loess Plateau, China[J]. Resources Science, 2014, 36 (5) : 10291036.]

[31] 马琼, 张勃, 王东, 等. 1960-2012 年甘肃黄土高原干旱时空变 化特征分析-基于标准化降水蒸散指数 [J]. 资源科学, 2014, 36 (9) : 1834-1841. [Ma Q, Zhang B, Wang D, et al. The temporal and spatial distribution of drought on the Loess Plateau based on the standardized precipitation evapotranspiration index from 1960 to 2012[J]. Resources Science, 2014, 36(9): 1834-1841.]

[32] 李芬, 于文金, 张建新, 等. 干旱灾害评估研究进展 [J]. 地理科 学进展, 2011, 30(7): 891-898. [Li F, Yu W J, Zhang J X, et al. Review of drought disaster evaluation[J]. Progress in Geography, 2011,30(7): 891-898.]

[33] 鲍超,方创琳. 干早区水资源开发利用对生态环境影响的研究 进展与展望 [J]. 地理科学进展, 2008, 27(3): 38-46. [Bao C, Fang C L. Impact of water resources exploitation and utilization on eco- environment in arid area: progress and prospect[J]. Progress in Geography, 2008,27(3):38-46.]

[34] 王俊, 孙晶, 杨新军, 等. 基于 NDVI 的社会-生态系统多尺度干 扰分析-以甘肃省榆中县为例 [J]. 生态学报, 2009, 29(3): 16221628. [Wang J, Sun J, Yang X J, et al. An analysis of disturbance on social-ecological system at multiple scales based on NDVI, case study in Yuzhong county of Gansu Province[J]. Acta Ecologica Sinica, 2009, 29(3): 1622-1628.]
[35] 张调风, 张勃, 王小敏, 等. 基于综合气象干旱指数 (CI) 的干旱 时空动态格局分析-以甘肃省黄土高原区为例 [J]. 生态环境学 报, 2012,21 (1): 13-20. [Zhang T F, Zhang B, Wang X M, et al. Temporal and spatial analysis of drought for recent 50 years in Loess Plateau of Gansu province based on meteorological drought composite index[J]. Ecology and Environmental Sciences, 2012, 21(1): 13-20.]

[36] 中国气象局.中国气象科学数据共享服务网[EB/OL].(2016-0627) [2017-04-10]. http://cdc.cma.gov.cn. [China Meteorological Administration. China Meteorological Data Sharing Service Network[EB/OL]. (2016-06-27) [2017-04-10]. http://cdc.cma gov.cn.]

[37] 中国科学院. 地理空间数据云 [EB/OL].(2016-10-28)[2017-0410]. http://www.gscloud.cn. [Chinese Academy of Sciences. Geospatial Data Cloud[EB/OL]. (2016-10-28) [2017-04-10]. http:/ www.gscloud.cn.]

[38] United States Geological Survey. Remote Sensing and Landsat [EB/OL]. (2017-3-10)[2017-04-10]. http://glovis.usgs.gov.

[39] Gbetibouo G A, Claudia R, Rashid H. Mapping South African farming sector vulnerability to climate change and variability: a subnational assessment[J]. Ifpri Discussion Papers, 2009, 34 (3): 175-187.

[40] Huang L, Yang P, Ren S. The vulnerability assessment method for Beijing agricultural drought[J]. Advances in Information \& Communication Technology, 2014, 419: 269-280.

[41] Kim Y, Chung E S. Assessing climate change vulnerability with group multi- criteria decision making approaches[J]. Climatic Change, 2013, 121(2): 301-315.

[42] 石育中, 杨新军, 王婷. 陕南秦巴山区可持续生计安全评价及 其鲁棒性分析 [J]. 地理研究, 2016, 35(12): 2309-2321. [Shi Y Z, Yang X J, Wang T. An evaluation of sustainable livelihood security based on robustness analysis of the Qinba mountain region of Shaanxi Province, China[J]. Geographical Research, 2016,35(12):2309-2321.]

[43] 田亚平, 向清成, 王鹏. 区域人地耦合系统脆弱性及其评价指 标体系 [J]. 地理研究, 2013, 32(1): 55-63. [Tian Y P, Xiang Q C, Wang P. Regional coupled human- natural systems vulnerability and its evaluation indexes[J]. Geographical Research, 2013,32(1): 55-63.]

[44] 姚玉璧, 张强,李耀辉,等. 干旱灾害风险评估技术及其科学问 题与展望 $[J]$. 资源科学, 2013, 35(9): 1884-1897. [Yao Y B, Zhang Q, Li Y H, et al. Drought risk assessment technological progresses and problems [J]. Resources Science, 2013, 35 (9): 1884-1897.]

[45] 龙花楼, 刘彦随, 张小林, 等. 农业地理与乡村发展研究新近进 展[J]. 地理学报, 2014, 69(8): 1145-1158. [Long H L, Liu Y S, Zhang X L, et al. Recent progress in agricultural geography and rural development research[J]. Acta Geographica Sinica, 2014 , 
69(8): 1145-1158.]

[46] Rajesh K S, Murty H R. An overview of sustainability assessment methodologies[J]. Ecological Indicators, 2012, 15(1):281-299.

[47] Tate E. Social vulnerability indices: a comparative assessment using uncertainty and sensitivity analysis[J]. Natural Hazards, 2012, 63 (2): 325-347.

[48] Harrison P A, Holman I P, Berry P M. Assessing cross-sectoral climate change impacts, vulnerability and adaptation: an introduction to the CLIMSAVE project[J]. Climatic Change, 2015, 128(3-4): 153-167.

[49] 郭永锐, 张捷. 社区恢复力研究进展及其地理学研究议题 [J]. 地理科学进展, 2015, 34 (1) : 100-109. [Guo Y R, Zhang J. Research progress and themes of geography on community resilience[J]. Progress in Geography, 2015,34(1): 100-109.]

\title{
Spatio-temporal analysis of drought vulnerability on the Loess Plateau of China at town level
}

\author{
SHI Yuzhong1', LI Wenlong ${ }^{1,2}$, LU Daming1', WANG Ziqiao', YANG Xinjun ${ }^{1}$ \\ (1. College of Urban and Environmental Sciences, Northwest University, Xi' an 710127, China; \\ 2. College of Resources and Environment Economy, Inner Mongolia Finance and Economics College, Hohhot 010070, China)
}

\begin{abstract}
Drought vulnerability assessment plays an important role in studies on mitigation and adaptation to combat drought. The assessment on the drought vulnerability of the rural areas at town level provides a new viewpoint of human-environment system sustainability in arid and semiarid regions of northwestern China. In view of drought vulnerability assessment, we constructed an indicator system in three dimensions including exposure, sensitivity, and adaptive capacity, by adopting the comprehensive evaluation framework of drought vulnerability. We selected Yuzhong County, one of typical counties on the Loess Plateau, as the study area, and applied entropy evaluation method, drought vulnerability index, and the local spatial autocorrelation index to calculate indicator weights, the drought vulnerability index, and the spatial agglomeration respectively, based on statistical, meteorological and remote sensing data from 2002 to 2015 as model input. The main results include: (1) The drought vulnerability index varies greatly, with a clear rise or fall trend periodically from 2002 to 2015 ; (2) The number of towns with different drought vulnerability degrees ranging from high to low is middle, high, and low, and the number of towns with high drought vulnerability degree significantly increases; (3) The influential factors on drought vulnerability from high to low are annual precipitation, slope, annual mean air temperatures, drought area, net income of farmers, population density, and the proportion of agricultural population to total population, among which the annual precipitation is the main driver influencing the drought vulnerability; (4) In terms of spatial pattern of drought vulnerability, the hot spots are distributed in the south and north of Yuzhong County, while the cold spots are found in the central part of the county, indicating that there exists an obvious geographical agglomeration, and several towns in hot spot areas tend to be stable.
\end{abstract}

Key words : drought vulnerability index; Getis-Ord G*; spatial and temporal evolution; influencing factors; Loess Plateau 